\title{
One Step Beyond: From Social Protection Recipients to Citizens
}

\author{
Savina Tessitore*
}

Abstract This article confronts theoretical links between rights, citizenship and social protection, reviewing
discourses on rights and citizenship and revealing fault-lines and trade-offs. Through the Hunger Safety Net
Programme (HSNP), Productive Safety Net Programme (PSNP) and Mahatma Gandhi National Rural
Employment Guarantee Act (MGNREGA) cases, it outlines the political conditions for the uptake of social
policies. It reviews the scope of action of civil society, governments and donors and their impacts on the
politics of accountability, attempting to outline a role for social protection as a means to inclusive and
democratic citizenship.

\section{Introduction}

This article analyses social protection beyond its minimalist interpretation, as an instrument of social and economic transformation to redress conditions of injustice and exclusion that perpetuate poverty (Sabates-Wheeler and Devereux 2008). Such a wider framework raises several interconnected issues: if their objective is to strategically confront social vulnerability, programmes should explicitly aim at enhancing capability, agency, participation and freedom of choice. At the same time, if rights are a mark of citizenship, and the absence of rights a measure of the disempowerment at the root of poverty, a precondition for addressing unequal power relations should be to ground programmes in a social contract, ensuring the predictable benefits necessary to tackle poverty, framed as

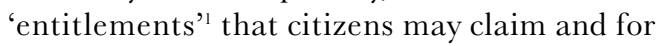
which governments may be held accountable.

The global expansion of social protection as an instrument to tackle long-standing poverty and vulnerability, the parallel shift to budget support in donor policies, and the move away from externally funded and managed projects towards government-owned programmes affect the way interventions are framed. Uptake of social protection is also influenced by its relevance for governments as political capital and propaganda instrument in electoral competitions. And while the shift towards national ownership is crucial to overcome the unreliability of external assistance, the role of donors and the question of their accountability in this new scenario remain unresolved. These sociopolitical dynamics constitute the backdrop to this article, which seeks to define the two-way relationship between social protection and citizenship through three national programmes that shed light on this.

\section{What we talk about when we talk about rights: unpacking the rights discourse} The latest version of what has been called the 'rise in rights' within development agencies (Chambers et al. 2003) emerged with the end of the cold war, when a new world order and an evolving nation-state system called for a stronger underpinning of democratic political rights and the rule of law. Meanwhile, the failure of structural adjustment policies to reduce poverty, after dramatically affecting the delivery of social services, opened the way to a concern with access to social and economic benefits for the poorest, and to a greater recognition of poverty's multidimensional nature, comprising lack of voice and rights. The rights discourse gained further momentum after the 2005 Paris Declaration moved the focus of international aid towards direct budget support, leading some donors to support the capacity of citizens to claim their rights and hold institutions accountable for delivery (Cornwall and NyamuMusembi 2005; Piron 2005). 


\subsection{Fault-lines I: frameworks and understandings of rights}

Framed in terms of 'human rights', donor agencies and Bretton Woods Institutions refer to rights through the language of norms, standards and principles enshrined in international frameworks that governments ratify and include unevenly in their national systems.

An approach to development based on human rights has certain strengths: most countries have signed up to treaties, they are widely accepted and their moral value is recognised. In general, they encompass all human beings beyond national citizenship, and are binding for State and nonState actors alike. They represent a shared normative framework against which to measure national legislations, and constitute an instrument for international organisations and social movements to uphold rights vis-à-vis governments.

On the other hand, there are limits to this approach, hindering its firm adoption. There is a suspicion that the rights discourse masks the imposition of new 'soft' conditions, more befitting of the contemporary language of 'partnership' (Cornwall and Nyamu-Musembi 2005). International human rights legislation is problematic to enforce, even when enshrined in national systems. Legal frameworks are hard to access for the poor and marginalised, who are most in need of their protection. Lastly, human rights as codified may contradict other norms and need to be negotiated to become tools through which the poorest may raise claims (Norton et al. 2002).

While a narrower legalistic definition is often implied when talking of rights-based approaches, fine-tuning the concept brings to light important fault-lines. A different pragmatic framework shifts the focus from bearers to claimants, factoring in rightsholders' own understanding of rights. It acknowledges local and individual definitions as well as the process of negotiating rights, arising from the struggles of social movements (Piron 2005). By addressing power relations and the way claims may challenge them, this definition places the issue firmly within the political domain, highlighting the agency of people living in poverty and their capacity to articulate and define their rights.

Another discussion centres on whether political and civil rights are a precondition for claiming and ensuring economic and social ones, or if the relationship is more complex, and the latter are not themselves a means to enable the realisation of the former, and therefore on a par with them (Gaventa 2002). Within constitutional theory, the typologies of political, civil and social rights have been argued to correspond to the parallel political, civil, and social dimensions of democracy, each viewed as necessary to grant the others, while limiting their excesses (Ferrajoli 2007). Related to these debates therefore, and likewise contested, is the idea of the indivisibility and interdependence of rights, calling for their simultaneous realisation and equal standing.

For practical purposes and conceptual clarity it is useful to distinguish between different points of view on the indivisibility and interdependence of rights.

Rights are easily undifferentiated in the perception of holders or claimants: often demands arising from movements' struggles cross both sets of rights, and European social policies were historically driven by workers' demands for social justice, equity and redistribution, in other words jointly for political, social and economic rights (Kabeer 2005). Historical antecedents (Stammers 2005) resonate with international covenants arguing that each right is essential to realise the others, and calling for their simultaneous application. Nevertheless, despite official commitments, many countries are reluctant to adopt UN Declarations within legal frameworks. The requirement to deliver all rights simultaneously, beyond the scope of a nation's citizenry, places a burden on national governments and constitutes a current limit to the applicability of this approach. ${ }^{2}$ This is also a question of translating principles into practice, and it may be unrealistic and perhaps not pragmatic to expect governments to bind themselves to the implementation of corresponding measures, exposing them to a high risk of failure for which they will be accountable.

\section{India's Mahatma Gandhi National Rural} Employment Guarantee Act (MGNREGA), grants 100 days labour per rural household at the minimum wage, according to demand. It is based on the right to work, with linkages to the right to food in its rationale and the right to information in its design. Activists' argument that different rights complement each other may also be reversed: for 
example, apart from other considerations at the root of their adoption, provisions on disclosure of information were found to limit implementation (Ambasta et al. 2008), and guaranteed employment may not necessarily be the best option to ensure food for all (MacAuslan 2006). The many difficulties in implementing MGNREGA seem to confirm that linking different rights in practice is problematic, particularly if food security is a preoccupation. It suggests that sometimes incremental universalism, starting with the most necessary goods, might be preferable, or that the right most critical for action should be prioritised.

\subsection{Fault-lines II: Users and shapers}

Related to the theory of rights is the concept of citizenship, defined, in liberal theory, as a status entitling individuals to universal rights bestowed by the state. Contemporary conceptualisations see citizenship as a practice rather than a given, characterised by 'the right to have rights' and to participate actively in their realisation (Gaventa 2002). In this view, the state entitles its citizens to social and economic rights to enable their participation in state-building and governing public goods, a relevant argument for the uptake of rights-based social protection policies, as will be argued below.

This broader definition challenges a purely legalistic interpretation, exposing its weaknesses: if legal frameworks are unable to include citizens' capacity to claim rights, or if citizenship is based on pre-existing excluding principles, or reinforces marginal identities, rights and legal frameworks become a means to further exclude and marginalise, countering the pro-poor goal of development programmes.

Different definitions of recipients of social security are revealing of evolving notions of citizenship, from beneficiaries of welfare, to clients provided with services, to citizens as holders and claimants of rights (Chambers et al. 2003). Another useful distinction, therefore, focuses on the difference between citizens as users of services and holders of 'consumer rights', and as agents and active makers of the policy spaces they inhabit - what Cornwall and Gaventa (2001) have called 'choosers and users' and 'makers and shapers'. In terms of development programming, this definition draws a line between people's involvement as beneficiaries of services through consultation processes aiming at improved management and delivery, and the different modalities of citizens' participation in deliberation and accountability processes.

Kenya's Hunger Safety Net Programme (HSNP) exemplifies how structural conditions can limit the scope of citizens' agency and the definition of rights within a social protection programme. The HSNP is a cash transfer programme targeting 60,000 households in pastoral areas of northern Kenya. Funded mainly by the UK's Department for International Development (DFID) and implemented by international NGOs including Oxfam GB, it aims to smooth consumption and protect the assets of some of Kenya's most vulnerable citizens. A rights component, designed by HelpAge International (HAI), champions 'accountability, transparency and... public participation' to ensure 'quality assurance provisions', and is 'charged with the empowerment of communities... and... of vulnerable groups' (Barrett 2008: 2, 8). It includes a programme of civic education and a grievance mechanism based on a charter of rights and responsibilities, an appeals service, and an effort to engage with local organisations.

Overall, the rights referred to do not apply beyond the narrow sphere of the HSNP, and instruments fostering 'empowerment' and 'participation' aim at protecting people as clients, to be provided with 'consumer rights'. Since the most vulnerable and socially excluded have more difficulties in accessing benefits, effective grievance, redressal and transparency mechanisms need to be a central concern of any intervention targeting them. Nevertheless, it is worth asking whether the historically marginalised groups living in this area could have been active in establishing the HSNP from its inception as 'makers and shapers', deepening the proclaimed empowerment and participation objectives. Different factors limited this possibility, including the minimal initial involvement of government, social movements, civil society and recipients, and the central position of foreign actors with partially overlapping mandates charged with its realisation. Ultimately, HSNP recipients rely on transfers (and rights) bequeathed from above by a foreign power and managed mainly by foreign organisations, both remote from a contractual relationship between the Kenyan state and its impoverished citizens. It is within this relationship, though, that politics to redress the long-standing destitution and marginalisation of members of these pastoralist 
communities should be enacted, to trigger a process of empowerment leading to their acquisition of full citizenship status.

\section{Rights, power and social policies}

The adoption of social policies is embedded in contextual relations of power, and the two-way links between politics and social protection determine the design and long-term outcome of policies. Parties' and governments' stance on social expenditure in favour of the most vulnerable should be interrogated through the lens of driving interests and incentives, keeping in mind that political impacts have feedback effects on policies. Social protection is critical political capital, irrespective of the form of government, as illustrated by India under colonial rule, and confirmed by the political history of famines in Ethiopia (Drèze and Sen 1990-91), two countries where social policies arising from an awareness of the destabilising power of food shortages have long been in place, beyond any push towards democratisation.

Besides its obvious negative character of patronage, politicisation can have the positive effect of putting social protection on political parties' agendas, turning it into a campaigning issue during elections (Devereux and White 2008). Other triggers and hurdles to the endorsement of social policies are forms of party systems and regimes, the position of leaderships and elites, capacity and buy-in of bureaucracies and differently influential Ministries, outreach of state structures beyond the formal sector, the dialectic between central and decentralised institutions, transparency and information, strategic policy priorities and, critically, democratic dynamics and a well-established social contract (Hickey 2008; Norton et al. 2002).

Both the Indian MGNREGA and the Ethiopian Productive Safety Net Programme (PSNP) are the result of negotiations, though very different circumstances set the stage for the governmentowned, rights-based Indian scheme, driven by civil society activism, and the governmentimplemented but largely donor-driven and discretionary Ethiopian programme.

\subsection{Civil society as driver: the case of the MGNREGA}

The MGNREGA is the outcome of a complex policy process. Its outstanding feature, a grounding in entitlements, may be traced to social movement activism in Rajasthan throughout the 1990 s, culminating in 2001 with a Public Interest Litigation (PIL) that implicated the Indian state in starvation deaths during a protracted drought. This gave momentum to a 'right to food' campaign that pressed for an Employment Guarantee Act (EGA). Social activists' demand for entitlement-based social security made them a crucial actor from the outset in the process leading to MGNREGA. The electoral success of the Congress Party, whose 2004 manifesto included a promise for an EGA, paved the way for its legal enactment, marked by an intense debate within and beyond the coalition in power and with social movements.

Underlying the controversies which accompanied most of the bill's clauses were conflicting interpretations of entitlements and the extent of redistribution they entailed, with various attempts to dilute the guarantee of employment, mainly due to financial concerns. These manoeuvres were pre-empted by sustained mobilisation of civil society, ensuring that the bill's fundamental rights-based inspiration was not lost.

The debates to which the bill was subjected testify to MGNREGA's many objectives and the interests to which it caters. Nevertheless, neither the process through which it was established nor its outcomes are a simple reflection of these interests, and championing them was also tactically instrumental to the actors involved. The diagnosis of famines as lack of work, to be prevented through wage-based employment, goes far back in Indian history (Drèze and Sen 1990-91), favouring legislation based on the right to work, while limiting the search for alternative and possibly more appropriate solutions, such as cash transfers. Ultimately, converging interests gave rise to a scheme destined to be scaled-up nationally and unique in terms of its contractual basis and the many provisions accompanying it, empowering the rural poor to participate in its implementation and monitoring. Activists engaged in different phases of the process, both within and beyond the institutional setting, had a crucial role in reframing the discourse on public drought and hunger relief schemes in these terms.

Civil society's contribution in advocating for social protection policies and pressing for accountability, as 'maker' rather than 'user', is 
generally underestimated (Norton et al. 2002). On the other hand, social movements do not usually arise around issues directly tied to poverty, and though they often address its drivers, the poorest themselves seldom figure as protagonists of their struggles (Bebbington 2007). This raises a set of questions.

First is the conundrum of how to organise collective action by those whose exclusion is premised on their lack of organisation (Kabeer 2005). Second, what is the relationship between elite leadership of social movements and the poorest, who are the object of social policies and invoked in movements' campaigns, what are their reciprocal interests, how far do the former actually represent the latter, and what are the consequences of this relationship on democratic dialectics? Finally, Bebbington (2007: 814) states that 'the success and effectiveness of... reform initiatives are the greater when... pursued in... concert with social movement organizations'. It is worth asking, then, whether lack of social mobilisation affects the framing of rights, with consequences on citizens' capacity to claim them and hold institutions accountable.

In the Indian case, civil society militants were crucial advocates for the adoption of an employment guarantee scheme. The driving interests in ruling on an EGA at national level, however, were predominantly tied to political contingency and opportunistic attempts to win over support from the rural electorate to be garnered for future competitions, rather than to widespread activism of the rural poor. Although a strong link between social movements and those they purport to speak for should not be taken for granted, in this case, the insistence on designing rights-based provisions into the act testifies to an authentic preoccupation with empowerment of the rural poor on the part of activists, while success was also due to their catalytic capacity to mobilise sectors of the population to push for legislation and monitor outcomes when necessary.

\subsection{Reaching consensus between donors and government: the case of the PSNP}

Very different circumstances gave rise to the PSNP, which reached 8.2 million chronically foodinsecure Ethiopians in 2008, aiming to 'graduate' them into long-lasting food security. If the Indian process should be analysed in terms of the national political scenario, the backdrop to the
PSNP is the international debate on aid effectiveness, and the donor-recipient country relationship occupies centre-stage in its framing, interacting with autochthonous political culture and understandings of poverty.

The shared acknowledgement of social safety nets as a more appropriate response to chronic food insecurity resonated with the growing need of donors to demonstrate sustained impact of aid flows, and their adoption of budget support as favoured aid modality. In turn, the government was pressed to overcome dependency on foreign aid, also in view of a long-standing attention to food production and self-sufficiency, and considering that food shortages have been a political liability for past autocratic Ethiopian rulers. Donors' initial priorities clashed with the government's political agenda and its discourses on poverty reduction, and a solution was reached only after much discussion and compromise on all sides (IDL Group 2007).

Ethiopia has a long tradition of authoritarian rule, mirroring a broader culture characterised by hierarchy and inequality, ambiguity and lack of transparency, operating at different levels (Vaughan and Tronvoll 2003). Since coming to power, the party in government strategically employed rural development and poverty reduction policies to win the support of rural constituencies. These characteristics of the political milieu shed light on the government's motives to engage in such an ambitious scheme, on one side, and on the limits to civil society's participation in establishing it, on the other.

Realistically, the programme's negotiated features should be flagged as a remarkable outcome, considering the initial discrepancy of their objectives. However, it also resulted in the interests of the poor being subordinated to the way poverty reduction was framed by the two actors occupying centre-stage. The difficulty for alternative points of view to emerge publicly, as the motor of policy debates centred on rights, further limited a more deliberative process.

The paradox of the Ethiopian government's preoccupation with widespread food security going hand in hand with a restricted democratic space reveals a complex relationship between the political will to prevent famines and social and political arrangements. It suggests that a right to 
food is a necessity not just for citizens to be protected from famine risk, but for the difference in the degree to which this protection is commanded through entitlements, rather than granted by an illiberal government fearful of losing its hold on the population.

\subsection{Donors and accountability}

International agencies often influence social protection in countries where they intervene, at times as its main drivers. The simultaneous endorsement of rights-based development by some elements of the donor community, though, is not unproblematic, raising the question of whether citizens' rights can be imported by donors and through aid, and what the implications of doing so are for international relations.

The rationale for the intervention of international actors to reduce poverty has been invoked in terms of their burden as duty-bearers. Assertions of their responsibility for the huge inequalities at the heart of world poverty rest on historical factors since, it is said, inequalities are rooted in the exploitation of low-income countries' resources, and presently rest on the imposition of a global order perpetuating unequal access and distribution (Pogge 2007). Whether grounded in charity or justice, the issue of donor initiatives raises the question of realising forms of accountability to conceive of social policies within a social contract.

The problems this raises are well illustrated in the rolling out of the HSNP, where one NGO holds another to account beyond any legally enforceable claims, and the functioning of rightsbased provisions depends on the commitment of all involved and continuous donor prioritisation; two rather shaky assumptions to build on. Despite a carefully designed complaints mechanism, implementing agencies are only ideally responsible to recipients, while to all intents under a contractual obligation to the donor. This has a direct impact on the two dimensions of accountability, resulting in weak answerability and non-existent enforceability of rights. While the HSNP's provisions take care of one set of accountability concerns, they do so within a narrow extra-legal framework.

One final observation concerns the relationship between rights and empowerment. Although it is generally true that 'to act as citizen requires a sense of agency and acting as citizens in turn fosters that sense of agency' (Kabeer 2002: 20), there is no direct relationship between rights and empowerment, even if nominal rights can contribute to empowerment and empowerment to making nominal rights meaningful (Fox 2007). Social protection measures aiming at tackling power relations would gain a place in this incomplete equation by being a means of empowering citizens as well as an entitlement they can legally claim.

\section{Conclusion: social protection as a means to citizenship}

This discussion attempted to define the conditions for a greater role of end-users in social protection, both as claimants of rights and as active participants in determining programmes. Finally, for social protection to move beyond discretionary interventions to predictable government policies grounded in citizens' rights, relationships between citizens and institutions need to change. There is space for an active role of recipients both as users who resort to grievance mechanisms or use disclosed information for better delivery, and as makers and shapers who claim rights, demand them to be inscribed in national constitutions, and hold states accountable for their full implementation.

Ultimately, a social protection intervention aimed at sustainable poverty and vulnerability reduction and concerned with social justice demands political buy-in of national governments, the presence of catalytic social movements, and empowered users. In the long run, donors, who presently offer vital strategic, technical and financial support, should foster a contractual relationship between national actors, eventually leaving them to negotiate policies within the national political arena. 


\section{Notes}

* Thanks to Dolf te Lintelo for editorial comments and to Stephen Devereux for overall mentoring.

1 For the purpose of the present argument, a narrow definition of 'entitlements' is adopted as rights which may be justly claimed through the formal legal system, independently from whether they are actually granted by State interventions, customary law or established practices. Sen's (1981) use of the concept of

\section{References}

Ambasta, P.; Vijay Shankar, P.S. and Shah, M. (2008) 'Two Years of NREGA: The Road Ahead', Economic and Political Weekly, 23 February

Barrett, S. (2008) Achieving Accountability in Cash Transfer Programmes: The Case of the Social Protection Rights Component of the Kenya Hunger Safety Net Programme, London: HelpAge International

Bebbington, A. (2007) 'Social Movements and the Politicization of Chronic Poverty', Development and Change 38.5: 793-818

Chambers, R.; Gaventa, J.; Kabeer, N.; Morago, L.; Norton, A.; Nyamu, C.; Scoones, I.; Singh, R. and Shankland, A. (2003) 'The Rise of Rights: Rights-based Approaches to International Development', IDS Policy Briefing 17, Brighton: IDS

Cornwall, A. and Gaventa, J. (2001) From Users and Choosers to Makers and Shapers: Repositioning Participation in Social Policy, IDS Working Paper 127, Brighton: IDS

Cornwall, A. and Nyamu-Musembi C. (2005) 'Why Rights, Why Now? Reflections on the Rise of Rights in International Development Discourse', IDS Bulletin 36.1, Brighton: IDS

Devereux, S. (2001) 'Sen's Entitlement Approach: Critiques and Counter-critiques', Oxford Development Studies 29.3: 245-63

Devereux, S. and White, P. (2008) 'Social Protection in Africa: Can Evidence, Rights and Politics Converge?', paper prepared for the Social Protection for the Poorest in Africa - Learning from Experience Conference, Entebbe, Uganda, 8-10 September

Drèze, J. and Sen, A. (eds) (1990-91) The Political Economy of Hunger, Vol 2: Famine Prevention, Oxford: Clarendon Press

Ferrajoli, L. (2007) Principia Iuris: Teoria del Diritto e della Democrazia, Vol 2: Teoria della Democrazia [Principles ofJustice: Theory ofJustice and of Democracy, Vol 2: Theory of Democracy], Bari: Laterza entitlements as a tool to analyse the capacity of accessing and controlling resources to extract utilities affecting wellbeing is acknowledged but sidestepped, as are critical appraisals and extensions of the concept (but see Leach et al. 1999; Devereux 2001).

2 The principle of progressive realisation of rights does not preclude immediate obligations for State parties. See International Covenant on Economic, Social and Cultural Rights, www2.ohchr.org/english/law/cescr.htm.

Fox, J. (2007) Accountability Politics: Power and Voice in Rural Mexico, Oxford: Oxford University Press

Gaventa, J. (2002) 'Introduction: Exploring Citizenship, Participation, Accountability', IDS Bulletin 33.2: 1-11

Hickey, S. (2008) 'Conceptualising the Politics of Social Protection in Africa', in A. Barrientos and D. Hulme (eds), Social Protection for the Poor and Poorest: Concepts, Policies and Politics, Basingstoke: Palgrave Macmillan

IDL Group (2007) Building Consensus for Social Protection: Insights from Ethiopia's Productive Safety Nets Programme, London: Department for International Development (DFID)

Kabeer, N. (2005) 'Introduction' in N. Kabeer (ed.), Inclusive Citizenship: Meanings and Expressions, London: Zed Books

Kabeer, N. (2002) 'Citizenship, Affiliation and Exclusion: Perspectives from the South', IDS Bulletin 33.2: 12-23

Leach, M.; Mearns, R. and Scoones, I. (1999) 'Environmental Entitlements: Dynamics and Institutions in Community-Based Natural Resource Management', World Development 27.2: 225-47

MacAuslan, I. (2006) 'Working the System: the Passage of India's National Rural Employment Guarantee Act', unpublished draft article

Norton, A.; Conway, T. and Foster, M. (2002) 'Social Protection: Defining the Field of Action and Policy', Development Policy Review 2.5: 541-67

Piron, L.-H. (2005) 'Rights-Based Approaches and Bilateral Aid Agencies: More than a Metaphor?', IDS Bulletin 36.1: 19-30

Pogge, T. (ed.) (2007) Freedom From Poverty as a Human Right: Who Owes What to the Very Poor?, Oxford: Oxford University Press

Sabates-Wheeler, R. and Devereux, S. (2008) 'Transformative Social Protection: The 
Gurrency of Social Justice', in A. Barrientos and D. Hulme (eds), Social Protection for the Poor and Poorest: Risks, Needs and Rights, Basingstoke: Palgrave Macmillan

Sen, A. (1981) Poverty and Famines: An Essay on Entitlement and Deprivation, Oxford: Clarendon Press

Stammers, N. (2005) 'The Emergence of Human Rights in the North: Towards Historical
Re-evaluation', in Kabeer, N. (ed.), Inclusive Citizenship: Meanings and Expressions, London: Zed Books

Vaughan, S. and Tronvoll, K. (2003) The Culture of Power in Contemporary Ethiopian Political Life, Stockholm: Swedish International Development Cooperation Agency (Sida) 